\title{
ANTIOXIDANT ACTIVITY, AMINO ACID PROFILE AND MICROBIAL QUALITY OF BEBONTOT, A BALINESE TRADITIONAL FERMENTED CHICKEN MEAT PRODUCTS
}

\author{
OKARINI, I. A. ${ }^{1}$, H. PURNOMO ${ }^{2}$, AULANNI'AM ${ }^{3}$ AND L. E. RADIATI ${ }^{2}$ \\ ${ }^{1}$ Staff of Laboratory of Animal Food Technology, Faculty of Animal \\ Husbandry, Udayana University,Denpasar,Bali \\ ${ }^{2}$ Department of Animal Food Technology, Faculty of Animal Husbandry, Brawijaya University, \\ 3Department of Biochemistry,Faculty of Mathematics and Natural Sciences, Brawijaya University, \\ e-mail: i.aokarini@gmail.com
}

\begin{abstract}
Antioxidant activity, amino acids profile and microbial quality of raw bebontot of chicken meat of spent laying hen were investigated. The samples were prepared using meat dices $(1.5 \times 2.0 \mathrm{~cm})$ mixed with fresh ground coriander, garlic, galangal, white pepper, salt, sugar and coconut oil then wrapped in Areca catechu palm dried sheaths and finally fermented spontaneously by drying under the sun for 5 days. The results showed there was a decreasing in $\mathrm{pH}$ value, moisture content and 1,1-diphenyl-2-picrylhydrazyl radical scavenging activity of final products, while its total phenolic content was increasing. Glutamic acid was the most abundant amino acid in products after 5 days fementation, followed by tyrosine, aspartic acid, lysine, leucine and histidine. The total plate count and lactic acid bacteria counts were decreasing to $9.39 \mathrm{log} \mathrm{cfu} / \mathrm{g}$ and $8.98 \mathrm{log} \mathrm{cfu} / \mathrm{g}$; the Micrococcaceae was decreased to $5.31 \log \mathrm{cfu} / \mathrm{g}$; the yeast and moulds counts were increased to $8.58 \mathrm{log} \mathrm{cfu} / \mathrm{g}$ and $6.51 \mathrm{log} \mathrm{cfu} / \mathrm{g}$ at the final stage of fermentation. It can be concluded that bebontot chicken meat in this study is a good source of natural phenolic antioxidant, and the present microorganisms will provide the source for the selection of strains well adapted to the environment and able to compete with contaminant bacteria.
\end{abstract}

Keywords: antioxidant activity, amino acids, microbial profile, bebontot

\section{AKTIVITAS ANTIOKSIDAN, PROFIL ASAM AMINO DAN KUALITAS MIKROBA BEBONTOT DAGING AYAM PRODUK FERMENTASI TRADISIONAL BALI}

\begin{abstract}
ABSTRAK
Aktivitas antioksidan, profil asam amino dan kualitas mikroba bebontot daging ayam petelur afkir diselidiki. Sampel disiapkan dengan menggunakan daging (ukuran 1,5×2,0 cm) dicampur dengan bumbu ketumbar, bawang putih, lengkuas, lada putih, garam, gula dan minyak kelapa, kemudian dibungkus dengan pelepah pinang (areca catechu) kering dan difermentasi secara spontan dengan pengeringan di bawah sinar matahari selama 5 hari. Hasil penelitian menunjukkan terdapat penurunan nilai $\mathrm{pH}$, kadar air dan aktivitas antioksidan produk akhir, sementara kadar fenolik total meningkat. Asam glutamat adalah asam amino yang paling banyak dalam produk setelah 5 hari fermentasi, diikuti oleh tirosin, asam aspartat, lisin, leusin dan histidin. Jumlah total mikroba dan jumlah bakteri asam laktat menurun menjadi 9,39 log cfu/g dan 8,98 log cfu/g; micrococcaceae berkurang menjadi 5,31 log cfu/g; total ragi dan kapang meningkat menjadi 8,58 log cfu/g dan 6,51 log cfu/g pada tahap akhir fermentasi. Dapat disimpulkan bahwa bebontot daging ayam dalam penelitian ini merupakan sumber antioksidan fenolik alami yang baik, dan keberadaan mikroorganisme dalam produk dapat digunakan sebagai sumber untuk pemilihan strain yang baik dan disesuaikan dengan lingkungan yang mampu bersaing dengan bakteri kontaminan.
\end{abstract}

Kata kunci: aktivitas antioksidan, profil asam amino, mikroba, bebontot 


\section{INTRODUCTION}

Poultry meat from spent laying hen chicken is very popular in Bali as an excellent and an increasing important source of high-value animal protein. Okarini et al. (2013) reported that spent laying hen and Bali indigenous chicken breast fillet contain higher protein and lower fat compared to broiler breast fillet. Furthermore the essential amino acid content between Bali indigenous chicken with spent laying hen breast fillet was not signficantly difference, however the antioxidant activity of broiler fillet was significantly lower compared to either spent hen and Bali indigenous chicken.

Bioactive meat protein (the skeletal muscle tissue of red meat, fish and poultry) as well as bioactive peptides are part of a balanced diets, which could also be nutritionally beneficial as a source of essential amino acids (Udenigwe and Aluko, 2012). These bioactive peptides can be released by using specific microorganisms, especially protease from $\mathrm{LAB}$ in fermentation food processing, and enzyme-catalyzed proteolysis in vitro or in the digestive tract after human consumption (Arihara, 2006), because bacterial cultivation costs are relatively low (short time of maturation). Furthermore LAB and their products are considered safe (Agyei and Danquah, 2011). Rediscovery of traditional fermented meat products as functional food is an interesting direction, because the original characteristic of raw material (meat, fat, spices and starter culture) and technology (salting, fermentation, ripening drying, fermentation and drying procedures) are changed remarkably resulting in product with improved functionality (Arihara, 2006; Zhang et al., 2010). It is possible due to many proteins are hydrolyzed during fermentation and ripening and to accumulate quantities of biologically active peptides with the enhancement of the physiological activity or many peptides are multifunctional and exhibit more than one activity of the products (Arihara, 2006; Iroyukifujita et al., 2000; Jahan-Mihan et al., 2011; Liu et al., 2010).

Fermentations as an ancient method of extending shelf-life of meat product, while fermented sausages play a major role in meat industry (Zhang et al., 2010), because a significant number of biochemical, physical and microbiological reaction take place during the fermentation process (Flores et al., 2004). Whilst meat processing operation could increase oxidative stress by introducing oxygen, removal of nature antioxidant, destruction of endogenous antioxidant, and increasing pro-oxidative factors (Wojciak and Dolatowski, 2012). The ability of proteins to inhibit lipid oxidation makes them an important component of the antioxidant defence of biological tissues from which foods are produced, because protein are somewhat unique in this way compared to other food antioxidants, where they can potentially act as multifunctional antioxidants that can inhibit several different lipid oxidation pathways (Elias et al., 2008).

Arihantana (1981) noted that a Balinese traditional fermented product known as Bebontot or buntilan are prepared using mixed lean and fat pork meat, chopped into $1.5-2 \mathrm{~cm}$ cube and mixed with fresh ground spices consist of tumeric,galangal,aromatic ginger, ginger, garlic, chillies, pepper and salt, and this misture was then sundried. While Hartawan (2002) reported that this product was prepared traditionally in small-scale enterprises and in each region of Bali difference spices mixture used to produce bebontot, where it is also related to the drying environment condition However, there are no reports on some quality traits of fermented spent laying hen meat bebontot, therefore the aims of this study were to measure the antioxidant activity (total phenolic content and DPPH radical scavenging activity), amino acids profile and microbial quality of bebontot using spent hen layer breast meat produced in Bali island.

\section{MATERIALS AND METHODS}

\section{Bebontot or Buntilan Chicken Breast Meat Preparation}

Spent laying chicken (ISA-brown) after a period of laying of 76 weeks obtained from commercial poultry farms in central region of Bali were used as raw material in Bebontot preparation. All chickens were slaughtered at the university farm at the same time after a fasting period for $12 \mathrm{~h}$, and the skinless breast fillet (Musculus Pectoralis Superficialis), left and right breast muscles of each bird from those chicken were packed in polyethylene pouches and stored at $4^{\circ} \mathrm{C}$ for $24 \mathrm{~h}$ before used for bebontot processing. Meat chopped into 1.5-2 $\mathrm{cm}$ cube and mixed with fresh ground spices consist of coriander (12.5-15\%), garlic (25\%), galangal (35-37.5\%), in the part 1:2:3, white pepper (2\%), salt (8\%), sugar (10\%), and coconut oil (5\%) on weight raw material. Then it was wrapped with Areca catechu palm dried sheaths and finally dried under of the sun for 5 days (the afternoon temperature was $35-39^{\circ} \mathrm{C}$ and 28 $33^{\circ} \mathrm{C}$ at night).

Moisture content of bebontot samples was measured following method no. 950.46 AOAC, (2000). While pH of the samples were determined (method no. 981.12 AOAC., 2000; Jang et al., 2008) by homogenizing $5 \mathrm{~g}$ of samples with $25 \mathrm{ml}$ of distilled water, then homogenates were filtered and furthermore the $\mathrm{pH}$ of samples was measured with a pH meter (Model 720 P Istek,Inc.) at room temperature.

Total Phenolic Content 
Total phenolics content were determined calorimetrically using Folin-Ciocalteu reagent as described by Jang et al. (2008) with slight modifications. The bebontot chicken meat samples (5g) in distilled water $(15 \mathrm{~mL})$ was homogenized at 3000 rpm for $2 \mathrm{~min}$. Chloroform (9 $\mathrm{mL}$ ) was added to the homogenates and the mixture was shaken vigorously 2 to 3 times to separate the lipids. A 1-mL aliquot of diluted sample (1:4, vol/vol) was added to the Folin-Ciocalteu reagent $(500 \mu \mathrm{L})$, followed by addition of $1 \mathrm{~mL}$ of sodium carbonate solution (5\%). The reaction mixture was vortexed and the absorbance was measured with a spectrophotometer (SP-870 TURNER Barnstead USA) at $700 \mathrm{~nm}$ after incubation for $1 \mathrm{~h}$ at room temperature. Samples were measured in three replicates (o day and 5 days), each replicate were of 3 different bebontot samples and absorbance measured in two readings. Quantification was done based on the standard curve generated with gallic acid, and the standard calibration curve of gallic acid solution (10, 20, 30 and $40 \mathrm{mg} / \mathrm{L}$ ) was prepared using the similar procedure.

DPPH Radical Scavenging Activity

The Radical-Scavenging Assay: 1,1-Diphenyl-2picrylhydrazyl (DPPH) radical scavenging activity was estimated with the aqueous supernatant obtained from raw of bebontot chicken meat according to the method of Blois as described by Jang et al. (2008), with slight modifications. $0.1 \mathrm{ml}$ quantity of aqueous supernatant diluted to $5 \mathrm{ml}$ of water, then take into test tube $1.5 \mathrm{ml}$ and was added $1.5 \mathrm{~mL}$ of methanolic DPPH solution $(0.2 \mathrm{mM})$. The mixture was vortexed and left to stand at room temperature for $30 \mathrm{~min}$. A tube containing $1.5 \mathrm{~mL}$ of methanol and $1.5 \mathrm{~mL}$ of methanolic DPPH solution (o.2 $\mathrm{mM}$ ) served as the control. The absorbance of the solution was measured at $517 \mathrm{~nm}$ (SP-870 TURNER Barnstead USA). Each sample of o day and 5 days were prepared three replicates (each replicate was from three different bebontot samples) and absorbance measured in two replicate readings. The percentage of DPPH radical scavenging activity was obtained from the following equation:

Radical-scavenging activity (\%) =

$$
\left(1-\frac{\text { absorbance value of testing solution }}{\text { absorbance value of control solution }}\right) \times 100
$$

\section{Microbiological Analysis}

The bebontot or buntilan chicken meat samples were assayed for (1) aerobic plate counts, (2) lactic acid bacteria, (3) Micrococcaceae, (4) yeasts, (5) moulds and (6) coliforms. Ten grams of each sample were aseptically transferred to a sterile stomacher bag with $90 \mathrm{ml}$ of saline water (Sodium chloride $0.85 \%$ ). The preparation was mixed for 3 mins in a stomacher. Additional decimal dilutions were prepared, and the following analyses were carried out: (1) aerobic plate counts on Plate Count agar incubated for $48 \mathrm{~h}$ at $37^{\circ} \mathrm{C}$ (2) LAB on de Man-Rogosa Sharpe (MRS) agar incubated for $48 \mathrm{~h}$ at $37^{\circ} \mathrm{C}$ under restricted oxygen conditions (2 Gas-Pack envelopes; BBL, Baltimore, Maryland, USA) in an anaerobic jar (3) Micrococcaceae on mannitol salt agar (MSA, Pronadisa, cat.1062) incubated for $48 \mathrm{~h}$ at $37^{\circ} \mathrm{C}$ (4) Yeasts and Mould on Malt Extract Agar (MEA, Pronadisa cat.1038) incubated for $48 \mathrm{~h}$ at $30^{\circ} \mathrm{C}$ for yeasts, (5) for moulds incubated to $72 \mathrm{~h}$ at $30^{\circ} \mathrm{C}$, and (6) coliforms on Eosin Metilen Blue Agar (EMBA, Pronadisa, cat.1039) incubated for $24 \mathrm{~h}$ at $37^{\circ} \mathrm{C}$. After counted, means and standard deviations were calculated.

\section{Amino acids profile}

The amino acid profile of bebontot chicken meat samples was determined by the method of Antoine et al. (2001) with slightly modification. The sample obtained were $3 \mathrm{mg}$ protein or $0.015 \mathrm{~g}$ chicken breast meat / dry weight and then $1 \mathrm{ml} 6 \mathrm{~N} \mathrm{HCL}$ was added. The mixture was punged with $\mathbf{N}_{2}$ and then heated in the oven at $110^{\circ} \mathrm{C}$ for 24 hours. A sample was prepared after the $6 \mathrm{~N} \mathrm{HCl}$ hydrolysis then dissolved to $5 \mathrm{ml} 0.01 \mathrm{~N} \mathrm{HCl}$ and filtered using Millipore $0.45 \mu \mathrm{m}$ filter membrane (WHATMAN (R) diameter $25 \mathrm{~mm}$,followed by adding potassiumborate buffer ( $\mathrm{pH}$ 10.4).A $5 \mu \mathrm{L}$ quantity of hydrolisat protein sample was added with $25 \mu \mathrm{L}$ of OPA reagent and then injected after 1 minute of derivatization.

Mobile phase A was made up of $0.025 \mathrm{M}$ sodium acetate buffer ( $\mathrm{pH}$ 6.5) $0.5 \mathrm{~g}$ Na EDTA, $90 \mathrm{ml}$ methanol and $10 \mathrm{ml}$ THF (80:10:9:1) prepared from analytical grade dissolving to $1 \mathrm{~L}$ water Hi Pure. The $\mathrm{pH}$ of the acetate buffer (A buffer) was adjusted to 6.5 using $\mathrm{NaOH}$ solution, and mobile phase B buffer contain 95\% methanol on Hi Pure water. The mobile phases were ultrafiltered through Millipore filter having a

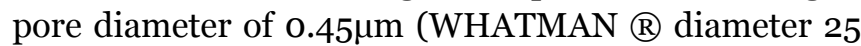
$\mathrm{mm}$ ) and degassed by sparging for 5 minutes with pure nitrogen. Gradient elution was generated using solvent delivery module Varian Pro Star Model Number 240 (Chromatography Systems, Walnut Creek, CA 94598 USA made in USA), was used for controlling the gradient and flow rate $(1.0 \mathrm{ml} / \mathrm{min})$ of the mobile phases.

OPA-thiol reagent was made up at least 24 hours before used by dissolving $50 \mathrm{mg}$ o-phthaldialdehyde in $4 \mathrm{ml}$ methanol, and $0.025 \mathrm{ml}$ mercapthoethanol was added. The mixture was throughly mixed,then 0.050 $\mathrm{ml}$ Brij-30 and $1 \mathrm{ml}$ borax buffer solution were added. The OPA-thiol reagent stored in the dark bottle or in a tightly closed container at $4^{\circ} \mathrm{C}$.

The amino acid profile of bebontot chicken meat were analyzed by cation exchange ICI Instrument High Performance Liquid Chromatography (HPLC) with column Ultra Techsphere ODS $3 \mu$ particle size, 4,6 mm x 
7,5 cm (PARKER 316 SGE PTY. LTD Victoria Australia) and O-phthaldialdehyde (OPA) precolumn derivatisation. The amino acid standard H (L-Alanine, L-Arginine, L-Aspartic Acid, L-Glutamic Acid, Gycine, L-Histidine, L-Isoleucine, L-Leucine, L-Lysine, L-Methionine, LPhenylalanine, L-Serine, L-Threonine, L-Tyrosine and L-Valine (PIERCE, Rockford Illinois 61105, USA) were used.

Amino acids were analyzed in three replicates (o, 1, 3 day and 5 days), each replicate was obtained from 3 different bebontot samples. The amino acid composition was expressed as mg of amino acid per $100 \mathrm{~g}(\%)$ of raw bebontot.

\section{Statistical analysis}

The experiments were carried out using completely randomized design with three replications, and the data obtained were analysed by using two-way analysis of variance (ANOVA) and Pearson Correlation. The differences among means were determined by Duncan Multiple Range test using SPSS version 13.0 (Chicago,Illinois, USA) at a level of significance of p<0.05 (Pramesti, 2005). Data were presented as means \pm standard deviation and each analysis of bebontot product were replicated for total phenol content and DPPH radical scavenging activity $(\mathrm{n}=3)$, amino acids content $(n=3)$ and for microbiological count $(n=3)$ to each drying or fermentation.

\section{RESULTS AND DISCUSSIONS}

Results of the physico-chemical components of the bebontot or buntilan are shown in Table 1. The $\mathrm{pH}$ of bebontot was decreased within traditional fermentation cycle (drying under sun) from initial value of $\mathrm{pH}$ around 6.2 to 4.6 in final fermentation (Table 1), and it was lower of Mhom, a Thai traditional meat sausages (Samappito et al., 2011); of Turkish sucuk, a Turkey traditional fermented sausages (Siriken et al., 2009); and of naturally fermented Italian sausages produced in the North East of Italy (Cocolin et al., 2001; Comi et al., 2005) and of Vallo di Diano, a Southern Italy of traditional fermented sausages (Casaburi et al., 2007), and it was higher of Androla, a Spanish traditional dry- cured sausages (Lorenzo et al., 2000). However, similar $\mathrm{pH}$ have been described for Turkish sucuks (Erkmen and Bozkurt, 2004); Northern Europe type sausages (Zanardi et al., 2004); Nham, a Thai fermented pork sausage(Visessanguan etal., 2006) and also of fermented sausages (21 days) as reported by Aro Aro et al. (2010). The decrease of $\mathrm{pH}$ in fermented meat products due to the decrease in the water-holding capacity of the meat proteins when $\mathrm{pH}$ approaches the isoelectric value. This condition not only improves its preservation, but also the drying process can bringing to extend the storage life to the high fermentation temperature. Especially in the afternoon $35-39^{\circ} \mathrm{C}$ with relative humidity (RH) $65^{-}$ $70 \%$; and $28-33^{\circ} \mathrm{C}$ with $\mathrm{RH} 55-60 \%$ in the night time. In the present study a significant positive correlation between $\mathrm{pH}$ value with $\mathrm{LAB}\left(\mathrm{R}^{2}=0.609\right)$ and total aerobic count $\left(\mathrm{R}^{2}=0.622\right)(\mathrm{p}<0.05)$; and between $\mathrm{pH}$ value with Micrococcaceae count $\left(\mathrm{R}^{2}=0.935\right)$, moisture content $\left(\mathrm{R}^{2}=0.849\right)$, total phenolic content $\left(\mathrm{R}^{2}=0.996\right)$ and radical DPPH scavenging activity $\left(\mathrm{R}^{2}=0.987\right)$ ( $\mathrm{p}<0.01$ ) were observed.

Moisture content of bebontot chicken meat decreased continuously during fermentation from $61.5 \%$ to $42.4 \%$ (Table 1). The results indicated that higher fermentation temperature caused faster dehydration and it is probably due to muscle proteins denaturation during fermentation. Siriken et al. (2009) reported that moisture content of Turkish sucuk sausage were between 30$47 \%$ with average $40.9 \%$; and for Spanish sausage were in the range of $18.2-62.2 \%$ (Lorenzo et al., 2000) and $40-46 \%$ for Italian sausage (Comi et al., 2005). In the present study a significant positive correlation between moisture content with $\mathrm{LAB}\left(\mathrm{R}^{2}=0.771\right)$, total plate count (TPC) $\left(\mathrm{R}^{2}=0.754\right)$, Micrococcaceae $\left(\mathrm{R}^{2}=0.965\right)$, coliform $\left(\mathrm{R}^{2}=0.723\right)$ and $\mathrm{pH}$ value $\left(\mathrm{R}^{2}=0.849\right)(\mathrm{p}<0.01)$ were also observed.

The rapid decrease in $\mathrm{pH}$ and moisture content were also directly related proporsionally to the increase of fermentation temperature and the higher growth rate of LAB. On other the hand Leroy et al. (2006) reported when glucose concentration is above a certain level, increased amounts of fermentable sugar which derived from the dissimilation of endogenous glucose in the batter primarily influence acidification rate, the final

Table 1. The $\mathrm{pH}$, moisture content, total phenolic content and radical scavenging activity of bebontot chicken meat

\begin{tabular}{ccccc}
\hline Time of fermentation (hours) & $\mathrm{pH}^{*}$ & Moisture (\%) & $\begin{array}{c}\text { Total phenolic* } \\
(\mathrm{GAE}=\mathrm{mg} / \mathrm{kg})\end{array}$ & DPPH RSA (\%)* \\
\hline 0 & $6.200 \pm 0.006^{\mathrm{a}}$ & $61.4971 \pm 0.014^{\mathrm{a}}$ & $25.269 \pm 0.533^{\mathrm{c}}$ & $52.111 \pm 0.180^{\mathrm{a}}$ \\
24 & $4.930 \pm 0.008^{\mathrm{b}}$ & $56.3944 \pm 0.064^{\mathrm{b}}$ & $22.283 \pm 0.533^{\mathrm{d}}$ & $31.626 \pm 0.090^{\mathrm{d}}$ \\
72 & $4.670 \pm 0.004^{\mathrm{c}}$ & $45.8820 \pm 0.064^{\mathrm{c}}$ & $32.363 \pm 1.067^{\mathrm{b}}$ & $35.580 \pm 0.090^{\mathrm{c}}$ \\
120 & $4.640 \pm 0.006^{\mathrm{d}}$ & $42.3965 \pm 0.041^{\mathrm{d}}$ & $45.429 \pm 0.533^{\mathrm{a}}$ & $38.140 \pm 0.045^{\mathrm{b}}$ \\
\hline
\end{tabular}

* a-d, Mean \pm Standard deviation $(n=3)$ values with different superscripts within same column differ significantly $(P<0.05)$, the results are expressed on fresh matter to each time of fermentation or drying. 
$\mathrm{pH}$ but neither the lag phase nor the rate of lactic acid formation. However the extent of $\mathrm{pH}$ drop also depends on the specific LAB, the manufacture technology such as temperature, raw materials, ripening time and the water activity of the drying sausage (Lorenzo et al., 2000; Cocolin et al., 2001; Comi et al., 2005; Casaburi et al., 2007; Lebert et al., 2007). In addition not only sugar added on formulation cause $\mathrm{pH}$ fall, but some herbs and spices (antioxidant and antimicrobial effect) could be used by indigenous LAB to help to rise an acidifying of meat products during fermentation (Hagen et al., 2000; Garcia, et al. 2001; Barriere et al., 2001). Hagen et al. (2000) reported that some herbs and spices have been found to stimulate the growth of LAB and thereby the rate of lactic acid formation to varying degrees dependent on the concentrations especially the content of manganese ions in the herbs or spices, and the bacterial strain.

\section{Antioxidant potential of bebontot spent laying chicken breast meat.}

The total phenolic content of bebontot products (Table 1) was lower than origin spent laying hen breast fillet as reported by Okarini et al. (2013), and increase continuously after $24 \mathrm{~h}$ until the end (5 days) of fermentation process. In the present study positive correlation between total phenolic content and total yeast $\left(\mathrm{R}^{2}=0.760\right)$, mould count $\left(\mathrm{R}^{2}=0.917\right)(\mathrm{p}<0.01)$ toward amount (12) of amino acids (one letter) as DESHGTYVILK $(\mathrm{p}<0.01)$ and $\mathrm{F}(\mathrm{p}<0.05)$ include essential amino acid (TVFILK), except RAM amino acids were observed. The high total phenolic content of bebontot products compared to fresh spent breast meat fillet, was possibly due to a number of spices and herbs wereadded to the formulation (coriander:garlic: galangal = 1: 2: 3). According to Mahae and Chaiseri (2009) and Neveu et al. (2010) the highest total polyphenols content were in dried coriander (2260.0 mg/100g fresh weight) and white pepper $(780.0 \mathrm{mg} / 100 \mathrm{~g}$ fresh weight); while total phenolics content of galangal in water extract was $8.25 \mathrm{mg} \mathrm{GAE} / \mathrm{g}$ extract and its essential oil were $5.01 \mathrm{mg} \mathrm{GAE} / \mathrm{g}$ extract, it also contained catechin 0.73 $\mathrm{mg} / \mathrm{g}$ extract and myricetin $14.60 \mathrm{mg} / \mathrm{g}$ extract. These compounds could interact with essential oil (volatile phenolic compounds) of herbs and spices together with protein of meat and some compounds of dried sheaths as wrapping material. A dried Arecha cathecu palm sheaths and their nuts contained arecoline, arecaidine, arecolidine, guvacine, choline, about $15 \%$ red tannin, about 14\% fat (Anon, 1960), therefore this palm sheaths could be used as bioactive packaging.

The high drying or fermentation temperature, released the water content and decrease the $\mathrm{pH}$ value, and this condition could promote interaction or is delivery to enzymatic activity between essential oil (volatile phenolics compound) of spices mix and meat proteins which could blocked of the hydrophilic amino groups and stimulate yeasts and moulds to grow. Kroll and Rawel (2001) noted that the reaction of myoglobin with the derivative substances is accompanied by a corresponding blocking of the hydrophilic amino groups. It indicated that enzymatic reaction activity of raw material, endogenous and microorganisms enzymes at high temperature, because the optimal temperature for enzymatic hydrolysis process at $35-40^{\circ} \mathrm{C}$. On the other hand the used of garlic, which according to Neveu et al. (2010) contained manganese ( $\mathrm{Mn}$ ) about $1.67 \mathrm{mg} / 100 g$; vitamin $\mathrm{C}$ about $8.21 \mathrm{mg} / 100 \mathrm{~g}$ fresh weight, added during preparation of bebontot could stimulate acid production. Hagen et al. (2000) reported that herbs and spices contain especially manganese ions, and is the primary factor to stimulate acid production to varying degrees depending on the concentration and present natural microorganisms strains. In the presence of micronutrients, especially manganese of herbs and spices may have a positive influence on the metabolism of natural microorganisms during fermentation, especially the growth of LAB and Micrococcaceae and thereby the rate of lactic acid fermentation to supply nutrients for stimulate the growth of yeasts and moulds. Bertoncelj et al. (2007); Decker (2009) and Dimitrios (2006) reported that polyphenolic compounds play a wide range of biological effects including antibacterial, anticarcinogenic, inhibition of atherosclerosis, antiviral, antithrombotic and these functions have been attributed to their antioxidant activity.

The radical scavenging activity of DPPH of bebontot is presented in Table 1 . The initial value was $52.11 \%$ of the batter (before wrapping) and decrease first day fermentation to $31.63 \%$ then increasing untilfinal stage of fermentation ( 5 days) were $38.14 \%$, and it is higher than origin spent chicken breast meat fillet (20.77\%). In the present study a significant positive correlation between radical scavenging activity of DPPH and $\mathrm{pH}$ value $\left(\mathrm{R}^{2}=0.987\right)(\mathrm{p}<0.01)$, and also of the Micrococcaceae count $\left(\mathrm{R}^{2}=0.681\right)(\mathrm{p}<0.05)$. It was probably due to the higher of essential oil as volatile phenolic compounds of herbs and spices which added during preparation of bebontot as described above causes protein oxidation due to high fermentation temperature at the beginning of the fermentation cycle, and increased proteolysis activity,and it is rapidly decreased $\mathrm{pH}$ value and water content. Santé-Lhoutellier et al. (2007) reported that the formation of aggregates changing both chemical and physical recognition sites showed that proteolysis susceptibility of protein increases at low oxidant level, in turn at a high oxidant level, and a decrease of proteolysis rate. The use of spices is very frequent in the case of 
sausages, which addition of spices not only contribute to color and flavor development, but also become a source of external contamination and antioxidant effect, and in some cases they have an inhibitory activity on microbial growth (Garcia, et al. 2001), in the present study coliform count was decreased. The reduction of $\mathrm{pH}$ value could increased radical scavenging activity of DPPH and decreased Micrococcaceae count of bebontot at the final fermentation stage ( 5 days).

The bebontot products in this study showed a higher radical scavenging activity of DPPH of isolate $\mathrm{LAB}$ which were dominated by Lactobaccillus plantarum and Pediococcus pentosaceus than of isolate LAB from the batter which were dominated by Pediococcus acidilactisi. The possible reason was the present of micronutrients, especially manganese of herbs and spices may have a positive influence on the metabolism of natural microorganisms during fermentation, especially the growth of LAB and Micrococcaceae (Igarashi et al., 1996; Hagen et al., 2000; Barriere et al., 2001; Garcia et al., 2001; Dimitrios, 2006; Martinez et al., 2006). Although Micrococcaceae are frequently mentioned as component of meat starter cultures as an important catalytic function that contributes to color stability and somehow prevention of lipid oxidation, this term generally refers to members of Staphylococcus genus, where the characterization of catalase and superoxide dismutase (SOD) in Staphylococcus carnosus and Staphylococcus xylosus have been reported (Barriere et al., 2001). Two groups of LAB which were a hemedependent catalase and nonheme Mn-containing catalase (Mn-dependent SOD) as reported by Igarashi et al. (1996). These probably due to that LAB isolates of bebontot contained the both of a heme-dependent catalase and nonheme Mn-containing catalase (Mndependent SOD) from spices was added. Furthermore, Neveu et al. (2010) noted that addition of garlic which contain manganese $(\mathrm{Mn})$ about $1.67 \mathrm{mg} / 100 \mathrm{~g}$ fresh weight; iron ( $\mathrm{Fe}$ ) about $1.70 \mathrm{mg} / 100$ fresh weight and coriander which also contain manganese $(\mathrm{Mn})$ about $16.3 \mathrm{mg} / 100 \mathrm{~g}$ fresh weight could effected the antioxidant activity of food. Frankel and Meyer (2000) also reported that some authors reported that antioxidant action becomes more complicated in food systems and the various mechanisms including free radical chain breaking, oxygen scavenging, metal chelating, and inhibition of oxidative enzymes, are effective. However, hydrophilic antioxidant are more active in bulk oil systems (to the case of bebontot product) but lipophilic antioxidant are more active in lipid suspended in aqueous systems like an oil-in-water emulsion (Frankel and Meyer, 2000), whilst Kim et al. (2007) reported several amino acids could have a function as antioxidant precursor.

\section{Amino acid content of bebontot spent laying chicken breast meat}

Amino acids content in present study significantly increased during fermentation of bebontot, except arginine and alanine (Table 2). It is interesting to note that on final fermentation of bebontot were significant highest amount of glutamic acid and tyrosine while aspartic acid and lysine were observed higher at o day (in the batter). It was similar to the results reported by Aro Aro et al. (2010) on 3 days fermentation of sausages without starter culture. The other authors were also suggested the similar increased amount of amino acids (glutamic acid, lysine, histidine, leucine, threonine, isoleucine, phenylalanine) of dry fermented sausages with used of commercial proteases (pronase E from Streptomyces griseus, aspartyl proteinase from Aspergillus oryzae) at 5 days ripening (Diaz et al., 1997; Bruna et al., 2000). While glutamic acid, tyrosine, aspartic acid, lysine, leucine, histidine, threonine, isoleucine, phenylalanine, valine, serine, and glycine were also observed higher concentration in the final (5 days) fermentation compared to the batter (before wrapping, o day). In the present study predominance of glutamic acid, and a similar pattern was also reported by other authors in different fermented sausages (Diaz et al., 1997; Bruna et al., 2000). This condition had been attributed to high fermentation temperature applied during drying process indicating that the highest enzymatic activity of the raw materials (spent chicken meat, concentration of herbs and spices and the wrapping materials of the batter), rather than from microorganisms as described by Lücke, (2000). Several authors have reported a major protein breakdown during fermentation of sausages resulting or release of free amino acids by muscle endopeptidases (cathepsins B, D) and microbial (Micrococcaceae, yeast and mould) proteinases, bound either to the cell wall or to the cell membrane (Lücke, 2000; Hughes et al. 2002; Candogan et al., 2009)). It is known that such activity in muscle show considerable variation, related to anatomical location, gender, genetic, animal age, and postmortem rate of pH drop (Toldrá and Flores, 2000; Claeys et al., 2000).

In the case of arginine, it is high concentration (3.16\%) of spent laying hen breast fillet and significant lower than of Bali indigenous chicken (Okarini et al., 2013), but after fermented product, bebontot used meat of spent hen, arginine content is low (Table 2), and it is probably due to arginine convertion to ornithine via arginine deiminase (ADI) pathway and supports the growth of lactobacilli in the latter stage of meat fermentation or were transformed to other compounds by action of the mould and yeast dependent of strains. A similar research results were reported by Sanz and 
Table 2. Amino acids profile of bebontot chicken meat

\begin{tabular}{|c|c|c|c|c|}
\hline \multirow{2}{*}{ Amino Acids* } & \multicolumn{4}{|c|}{ Time fermentation of bebontot } \\
\hline & 0 (hrs) & 24 (hrs) & 72 (hrs) & 120 (hrs) \\
\hline Aspartic Acid & $2.26 \pm 0.20^{b}$ & $2.02 \pm 0.51^{b c}$ & $3.00 \pm 0.11^{\mathrm{ac}}$ & $3.34 \pm 0.04^{a}$ \\
\hline Glutamic Acid & $5.19 \pm 0.32^{b}$ & $3.87 \pm 0.04^{b}$ & $6.33 \pm 0.08 \mathrm{ab}$ & $7.21 \pm 0.17^{\mathrm{a}}$ \\
\hline Serine & $0.92 \pm 0.03^{b}$ & $1.06 \pm 0.15 a^{b}$ & $1.12 \pm 0.02^{\mathrm{a}}$ & $1.25 \pm 0.04^{\mathrm{a}}$ \\
\hline Histidine & $1.29 \pm 0.07^{b}$ & $1.54 \pm 0.05 \mathrm{ab}$ & $1.85 \pm 0.07^{\mathrm{a}}$ & $2.02 \pm 0.10^{\mathrm{a}}$ \\
\hline Glycine & $0.81 \pm 0.07^{c}$ & $0.88 \pm 0.00^{b c}$ & $1.07 \pm 0.02^{\mathrm{ab}}$ & $1.20 \pm 0.08^{a}$ \\
\hline Threonine & $1.24 \pm 0.14^{c}$ & $1.28 \pm 0.04^{b c}$ & $1.66 \pm 0.04^{\mathrm{ab}}$ & $1.83 \pm 0.06^{a}$ \\
\hline Arginine & $0.93 \pm 0.03^{b}$ & $1.80 \pm 0.69^{\mathrm{ac}}$ & $1.13 \pm 0.00^{\mathrm{bc}}$ & $1.19 \pm 0.02^{b c}$ \\
\hline Alanine & $1.23 \pm 0.07^{\mathrm{a}}$ & $0.72 \pm 0.40^{\mathrm{a}}$ & $0.97 \pm 0.24^{\mathrm{a}}$ & $0.90 \pm 0.05^{a}$ \\
\hline Tyrosine & $1.97 \pm 0.23^{d}$ & $2.75 \pm 0.12^{\mathrm{C}}$ & $3.91 \pm 0.73^{b c}$ & $5.02 \pm 0.35^{\mathrm{a}}$ \\
\hline Methionine & $0.65 \pm 0.01^{b}$ & $1.06 \pm 0.44^{a}$ & $0.76 \pm 0.05^{\mathrm{ab}}$ & $0.93 \pm 0.03^{a}$ \\
\hline Valine & $1.07 \pm 0.08^{b}$ & $1.20 \pm 0.04^{a}$ & $1.27 \pm 0.00^{\mathrm{a}}$ & $1.48 \pm 0.05^{\mathrm{a}}$ \\
\hline Phenilalanine & $1.11 \pm 0.07^{b}$ & $1.49 \pm 0.35^{\mathrm{ab}}$ & $1.39 \pm 0.04^{\mathrm{ab}}$ & $1.61 \pm 0.08^{a}$ \\
\hline Isoleucine & $1.21 \pm 0.11^{b}$ & $1.37 \pm 0.03^{a}$ & $1.53 \pm 0.01^{\mathrm{a}}$ & $1.77 \pm 0.04^{\mathrm{a}}$ \\
\hline Leucine & $1.73 \pm 0.16^{c}$ & $1.70 \pm 0.27^{\mathrm{cb}}$ & $2.12 \pm 0.03 \mathrm{ab}$ & $2.48 \pm 0.09^{a}$ \\
\hline Lysine & $1.52 \pm 0.06^{c}$ & $1.74 \pm 0.18^{\mathrm{cb}}$ & $1.98 \pm 0.12^{\mathrm{ab}}$ & $2.77 \pm 0.23^{a}$ \\
\hline Total & $23.14 \pm 1.65$ & $24.48 \pm 3.31$ & $30.10 \pm 1.56$ & $35.00 \pm 1.43$ \\
\hline
\end{tabular}

* a-c, Mean \pm Standard deviation $(n=3)$ values with different superscripts with in same row differ significantly $(P<0.05)$. The results are expressed as mg/100g of fresh matter to each time of fermentation or drying.

Toldrá (2002); Chaillou et al. (2005); Hüfner and Hertel (2008) whom had characterised arginine-specific aminopeptidase activity in Lactobacillus sakei during sausage fermentation, which is important to release of amino acids for used of energy production, when the environmental and ecological to stress condition where sugar concentration declines. A similar results was also reported by Diaz et al. (1997) and Bruna et al. (2000).

In the present study significant positive correlation between 12 amino acids and total phenolic content was observed, and this is possibly due to the presence of herbs (galangal, garlic) and spices (coriander seed, white pepper) with their essential oils (volatile phenolic compounds) on the recipe formulation and material wrapping (Areca cathecu sheets) of bebontot. Therefore it could be considered as sources of natural phenolic antioxidants. It probably as described by Elias et al. (2008) that many amino acids with antioxidant potential can be buried within the protein core where they are inaccessible to prooxidants. Whilst Kroll and Rawel (2001) reported that reactivity of the phenolic compounds is influenced by the number and the position of the hydroxyl group, where free amino group of proteins were blocked, and the reaction is very $\mathrm{pH}$-dependent conditions. The colour stability of bebontot (at final $\mathrm{pH} 4.64$ ), was probably as a result of interaction of phenolic promotion with blocking of the hydrophilic amino groups. Kroll and Rawel (2001) noted that the reaction of myoglobin with the derivative substances is accompanied by a corresponding blocking of the hydrophilic amino groups. Anyway, both amino acid fermentation and antioxidant characteristic are probably more important as selective criteria for flavor- enhancing starter bacteria than their lipolytic and proteolyses properties (Lücke, 2000).

Beneficial of amino acids of bebontot as antioxidant in the present study was showed to the increase amount of glutamic acid until $60 \%$ and tyrosine 6.5 folds higher, where both have the function as neurotransmitter and free radical scavenging. However the others amino acids amount also increased until final fermentation e.g. aspartic acid (67\%), serine (36\%), glycine (58\%), methionine (82\%), isoleucine (54\%), histidine (60\%) compared to the original spent laying breast meat fillet. In the present study 30\% of total hydrophilic amino acids were increased at 5 days of the fermentation. Especially the highest tyrosine (alpha-amino-p-hydroxyhydrocinnamic acid) amount in bebontot chicken meat in this study (Table 2) was probably due to high galangal concentration on spices and herb mixture. Mahae and Chaiseri (2009) was also noted that there was high amount of similar compound ( $p$-hydroxy cinnamaldehyde) found in the chloroform extract of galangal rhizome.

\section{Microbiological quality of bebontot spent laying chicken breast meat}

The microorganisms count of bebontot is presented in Table 3, and the initial total plate count or total aerobic mesophilic flora showed were $9.55 \mathrm{log} \mathrm{cfu} / \mathrm{g}$ (before wrapping) and a slight decrease to 9.39 log cfu/g at the end of fermentation, it is higher of the results as reported by Cocolin et al. (2001); Comi et al. (2005); Aro Aro et al. (2010) and Samappito et al. (2011). These differences were probably due to the variations in type and amount of raw material, fermentation and drying condition lead to an extended diversity concerning 
the dominating microorganisms, given rise to a wide range of products with unique sensorial traits. Lebert et al. (2007) reported that type of microorganism development in traditional meat products is related to the diversity in formulation, and to the fermentation and ripening practices, it could be very different in terms of raw material, temperature, duration and relative humidity. In the present study positive correlation between total plate count and decrease of moisture content $\left(\mathrm{R}^{2}=0.754\right)(\mathrm{p}<0.01), \mathrm{pH}\left(\mathrm{R}^{2}=0.622\right)$, coliform $\left(\mathrm{R}^{2}=0.617\right)$ and Micrococcaceae count $\left(\mathrm{R}^{2}=0.629\right)$ $(\mathrm{p}<0.05)$ during fermentation was also observed.

The average LAB counts were $9.56 \mathrm{log} \mathrm{cfu} / \mathrm{g}$ (before wrapping), and then a slight decrease to 8.98 $\log \mathrm{cfu} / \mathrm{g}$, respectively on 5 days fermentation (Table 3). This result was quite similar to those reported by Aro Aro et al. (2010) and Cocolin et al. (2001); and higher than the one reported by Comi et al. (2005) and Samappito et al. (2011) at the final fermentation stage of their meat product samples. The LAB constitute the major or dominant microorganisms at the end of the fermentation or ripening stage, and it is well known that high acidification rates are usually accompanied by fast $\mathrm{LAB}$ growth rates in the fermented sausages (Lebert et al., 2007). However, increased lactic acid production by LAB in the presence of glucose has been noticed in spite of an unchanged specific growth rate, whilst the additional energy obtained from direct fermentation of glucose is used for functions other than growth (Leroy et al., 2006). A significant positive correlation between $\mathrm{pH}$ value with $\mathrm{LAB}\left(\mathrm{R}^{2}=0.609\right)(\mathrm{p}<0.05)$ was observed in prsent study and it was in agreement with the one described by Cocolin et al. (2001).

The initial amount of Micrococcaceae on bebontot chicken meat were $6.43 \mathrm{log} \mathrm{cfu} / \mathrm{g}$ and decreased after 5 days to $5.31 \mathrm{log} \mathrm{cfu} / \mathrm{g}$ (Table 3). This result was similar to the one at the end of seasoning of natural fermented Italian sausages reported by Comi et al. (2005) and Cocolin et al. (2001) and slightly higher compared to the one as reported by Samappito et al. (2011). These differences probably due to the growth of Micrococcaceae appeared to be significantly affected by acidification of bebontot or by the inability to compete with the natural flora. The Micrococcaceae strains produce proteases which is able to induce meat protein degradation resulting in the release of peptides and amino acids, and neutralize the organic acids produced by LAB in first stages of the fermentation (Cocolin et al., 2001). A positive correlation between Micrococcaceae count and $\mathrm{pH}\left(\mathrm{R}^{2}=0.935\right)$ and also between Micrococcaceae count and moisture content $\left(\mathrm{R}^{2}=0.965\right)(\mathrm{p}<0.01)$ were also observed in this study. This was in agreement with Casaburi et al. (2007) results who considered acidification, higher temperature and anaerobic condition to be the main cause of Micrococcaceae inhibition in dry fermented sausages.

The highest increase of yeast count of bebontot was observed at initial stage i.e. $6.80 \mathrm{log} \mathrm{cfu} / \mathrm{g}$ and increased to $8.58 \mathrm{log} \mathrm{cfu} / \mathrm{g}$ at the final stage of fermentation (Table 3). These results were slightly higher than those reported on Spanish fermented sausages (Encinas et al., 2000); naturally fermented sausages produced in the North East of Italy (Comi et al., 2005); and of Mhom, a Thai traditional meat sausages (Samappito et al., 2011). The increase of yeasts was probably due to raw material on formulation of bebontot and also to the decreased of moisture content by the effect of high fermentation temperature and diameter of products. Encinas et al. (2000) also noted that high temperature during fermentation and size of samples could affected its moisture content. According to Bruna et al. (2000) and Bruna et al. (2003) the most influential variables were proteinase, aminopeptidase and a carboxipeptidase. In this study a significant positive correlation between yeast count and total phenolic $\left(\mathrm{R}^{2}=0.760, \mathrm{p}<0.01\right)$ and also lysine content $\left(\mathrm{R}^{2}=0.688, \mathrm{p}<0.05\right)$ were also observed. Kim et al. (2007) reported that function of lysine was important to transport of long-chain fatty acids into mitochondria for oxidation and storage of energy as acetylcarnitine.

The initial amount of moulds in bebontot was 2.48 $\log \mathrm{cfu} / \mathrm{g}$ and at final stage of fermentation was $6.51 \mathrm{log}$ $\mathrm{cfu} / \mathrm{g}$ (Table 3), and this result was similar to the one reported by Comi et al. (2005) at o day, but of variation as described by Samappito et al. (2011) at maximum levels of about $6.86 \mathrm{log} \mathrm{cfu} / \mathrm{g}$. In this study a significant positive correlation between moulds count and total phenolic content $\left(\mathrm{R}^{2}=0.917\right)(\mathrm{p}<0.01)$ toward amount (12) of amino acids (one letter) as DESHGTYVILK $(\mathrm{p}<0.01)$ and $\mathrm{F}(\mathrm{p}<0.05)$ include essential amino acid (TVFILK), except RAM amino acids were observed. The results indicated that increase of moulds count also followed by an increase of amino acids and total phenolic content at the final fermentation stage of bebontot products. Bruna et al. (2003) also observed a similar pattern on dry fermented sausages. The growth of yeasts and moulds in bebontot during spontaneous fermentation was probably due to an increased of metabolic activity of natural microorganisms present in raw material at low $\mathrm{pH}$, and the high temperature of drying (on local climate conditions) as a consequence of higher availability of amino acids released by the action of enzymatic of wild strains of yeast and mould.

In the present study a significant positive correlation between decrease on coliform count (Table 3) at final fermentation (5.2 to $4.6 \log \mathrm{cfu} / \mathrm{g}$ ) and moisture content $\left(\mathrm{R}^{2}=0.723, \mathrm{p}<0.01\right)$ was observed. Whilst lower of 
Table 3. Microbial profile of bebontot chicken meat

\begin{tabular}{|c|c|c|c|c|}
\hline \multirow{2}{*}{ Microbial profile* } & \multicolumn{4}{|c|}{ Time of fermentation (hours) } \\
\hline & 0 & 24 & 72 & 120 \\
\hline LAB (log cfu/g) & $9.56 \pm 0.19^{a}$ & $9.43 \pm 0.02^{a}$ & $9.41 \pm 0.02^{a}$ & $8.98 \pm 0.01^{b}$ \\
\hline TPC (log cfu/g) & $9.55 \pm 0.02^{a}$ & $9.54 \pm 0.02^{a}$ & $9.18 \pm 0.02^{c}$ & $9.39 \pm 0.02^{b}$ \\
\hline Coliform (log cfu/g) & $5.20 \pm 0.02^{b}$ & $5.85 \pm 0.02^{a}$ & $4.88 \pm 0.02^{c}$ & $4.62 \pm 0.02^{d}$ \\
\hline Micrococcaceae (log cfu/g) & $6.43 \pm 0.02^{a}$ & $5.89 \pm 0.02^{b}$ & $5.59 \pm 0.02^{c}$ & $5.31 \pm 0.02^{d}$ \\
\hline Yeast (log cfu/g) & $6.80 \pm 0.02^{b}$ & $6.64 \pm 0.02^{c}$ & $6.03 \pm 0.01^{d}$ & $8.58 \pm 0.02^{a}$ \\
\hline Mould (log cfu/g) & $2.48 \pm 0.02^{c}$ & $2.30 \pm 0.02^{d}$ & $5.73 \pm 0.02^{b}$ & $6.51 \pm 0.01^{a}$ \\
\hline
\end{tabular}

* a-d,Mean \pm Standard deviation $(n=3)$ values with different superscripts with in same row differ significantly $(P<0.05)$, the results are expressed on fresh matter to each time of fermentation or drying.

moisture content were also affected by lower of $\mathrm{pH}$ and higher of total phenolic content during drying or fermentation, and it is probably due to the high temperature of drying and addition of some herbs and spices mix on the formulation. Garcia et al.( 2001) and Martinez et al. (2006) noted that herbs and spices could be a source of external contamination and antioxidant effect, and in some cases they have an inhibitory activity on microorganisms growth. The inhibition activity against microorganisms of herbs and spices during bebontot preparation could be the cause of reduction of coliform count. The coliform count in this study was slightly lower than the one reported by Comi et al. (2005) on the present of fecal enterococci in natural fermented sausages.

\section{CONCLUSIONS}

The natural fermentation of bebontot or buntilan of chicken breast meat from spent laying hen under the sun during for 5 days, suggested that bioactive components were assessed by increase of the total phenolic content, DPPH radical scavenging activity, total hydrophilic amino acids, and essential amino acids was related with the increase of LAB, TPC, yeasts, moulds and decrease of Micrococcaceae, coliform count, $\mathrm{pH}$ and moisture content. The highest content of glutamic acid, tyrosine, aspartic acid and lysine during fermentation of bebontot chicken meat of spent laying hen may account for its higher effectiveness as an antioxidant compare to the batter (before wrapping). This product is a good as source of natural phenolic antioxidant, they have nutritional importance and/or the potential for application in the promotion of health and prevention against damages caused by radicals. The present microorganisms of bebontot chicken meat in this study will provide the source for the selection of strains well adapted to the environment and able to compete with contaminant bacteria.

\section{REFERENCES}

Agyei, D., and Danquah, K. 2011. Industrial-scale manufacturing of pharmaceutical-grade bioactive peptides. Biotech. Adv. 29:272-277

Anonymous. 1960. The Merck Index Of Chemicals And Drugs ( $7^{\text {th }}$ ed.). In P. G. Stecher (Ed.), (pp.97-98). MERCK \& Co., Inc. Rahway, N. J., U. S. A.

Antoine, F.R, Wie,C.I., Littell, Quinn,B.P, Hogle, A.D. and Marshall, M.D. 2001. Free amino acid in dark- and white- muscle fish as determined by o-phthaldialdehyde precolumn derivatization. J. Food Sci.: Food Chem. Toxic. 66(1):72-77

AOAC. 2000. Official Methods of Analysis of AOAC international $\left(17^{\text {th }}\right.$ ed.). Association of Official Analytical Chemists, Gaithersburg, Maryland. USA.

Arihantana, M.B. 1981. Production and Stability of Bebontot. M.App.Sc Thesis Department of Food Science and Technology, Univ. of New South Wales, Sydney.

Arihara, K. 2006. Strategies for designing novel functional meat products. Meat Sci. 74:219-229

Aro Aro, JM., Nyam-Osor, P., Tsuji, K., Shimada, K-I., Fukushima, M. and Sekikawa, M. 2010. The effect of starter cultures on proteolytic changes and amino acid content in fermented sausages. Food Chem. 119:279-285

Barriere, C., Leroy-Setrin, S., and Talon, R. 2001. Characterization of catalase and superoxide dismutase in Staphylococcus carnosus 833 strain. J. App.Micro. 91:514-519

Bertoncelj, G., Dobersek, U., Jamnik, M., and Golob, T. 2007. Evaluation of the phenolic content, antioxidant activity and colour of Slovenian honey. Food Chem. 105:822-828

Bruna, JM., Fernández, M., Hierro, E.M., Ordóñez, J.-A., and De la Hoz, L. 2000. Combined use of pronase $\mathrm{E}$ and a fungal extract (Pennicillium aurantiogriseum) to potentiate the sensory characteristic of dry fermented sausages. Meat Sci. 54:135-145

Bruna, JM., Hierro, E.M., De la Hoz, L., Mottram, D.S., Fernández, M., and Ordóñez, J.-A. 2003. Changes 
in selected biochemical and sensory parameters as affected by the superficial inoculation of Penicillium camemberti on dry fermented sausages. Int. J. Food Micro. 85:111-125

Candogan, K., Wardlaw, F. B., and Acton, J. C. 2009. Effect of starter culture on proteolytic changes during processing of fermented beef sausages. Food Chem. 116:731-737

Casaburi, A., Aristoy, M.-C., Cavella, S., Di Monaco, R., Ercolini, D., Toldrá, F., and Villani, F. 2007. Biochemical and sensory characteristics of traditional fermented sausages of Vallo di Diano (Southern Italy) as affected by the use of starter cultures. Meat Sci. 76:295-307

Chaillou, S., M. Champomier-Verges, M.Cornet, A. Crutz-Le Coq, A. Dudez, V. Martin, S. Beaufils, E. Darbon-Rongere Bossy, R. Loux, and M. Zagorec. 2005. The complete genome sequence of the meatborne latic acid bacterium Lactobacillus sakei $23 \mathrm{~K}$. Nature Biotech. 23:1527-1533

Claeys, E., De Smet, S., Demeyer, D., Geers, R., and Buys, N. 2000. Muscle enzyme activities in two pig lines. Meat Sci. 57:257-263

Cocolin, L., Manzano, M., Aggio, D.,Cantoni, C., and Comi, G. 2001. A novel polymerase chain reaction (PCR)-denaturing gradient gel electrophoresis (DGGE) for the identification of Micrococcaceae strains involved in meat fermentations. Its application to naturally fermented Italian sausages. Meat Sci. 57:59-64

Comi, G., Urso, R., Iacumin, L., Rantsiou, K., Cattaneo, P., Cantoni, C., and Cocolin, L. 2005. Characterisation of naturally fermented sausages produced in the North East of Italy. Meat Sci. 69: 381-392

Decker, EA. 2009. The role of phenolics, conjugated linoleic acid, carnosine, and pyrroloquinoline quinine as nonessential dietary antioxidants. Nutri. Rev. 53(3): 49-58

Diaz, O., Fernández, M., García de Fernando, G.-D., De la Hoz, L., and Ordóñez, J.-A. 1997. Proteolysis in dry fermented sausages: the effect of selected exogenous proteases. Meat Sci. 46 (1): 115-128

Dimitrios, B. 2006. Sources of natural phenolic antioxidants. Trends in Food Sci. \& Tech. 17:505-512

Elias, R. J., S.S. Kellerby and E.A. Decker. 2008. Antioxidant activity of proteins and peptides. Critical Rev. of Food Sci. and Nutri. 48:430-441. Accessed date 24-04-2012 from http://dx.doi. org/10.1080/10408390701425615.

Encinas, J-P., López-Diaz, T-M., García-López, M-L., Andres, O., and Benito, M. 2000. Yeast populations on Spanish fermented sausages. Meat Sci. 54:203-208

Erkmen, O., and Bozkurt, H. 2004. Quality characteristics of retailed sucuk (Turkish dry-fermented sausages).
Food Tech. and Biotech. 24:260-270

Flores, M., Durá, M.A., Marco, A., and Toldrá, F. 2004. Effect of Debaryomyces spp. On aroma formation and sensory quality of dry-fermented sausages. Meat Sci. 68:439-446

Frankel, E.N., and Meyer, AS. 2000. The problems of using one-dimensional methods to evaluate multifunctional food and biological antioxidants. J. Sci. Food Agric. 80:1925-1941

Garcia, Iracheta, F., Galvan, F., and Heredia, N. 2001. Microbiological survey of retail herbs and spices from Mexican markets. J. Food Protec. 64(1):99-103

Hagen, BF., Naes, H. and Holck, AL. 2000. Meat starters have individual requirements for $\mathrm{Mn}^{2+}$. Meat Sci. 55:161-168

Hartawan, M. 2002. Identifikasi Bakteri Asam Laktat, Perubahan Mikrobiologis dan Biokimiawi Selama Fermentasi Bebontot. Thesis. Program Pascasarjana Program Study Bioteknologi Pertanian Univ. Udayana Denpasar.

Hüfner, E., and C. Hertel. 2008. Improvement of raw sausage fermentation by stress-conditioning of the starter organism Lactobacillus sakei. Curr. Micro. 57(5):490-496

Hughes, M.-C., Kerry, J.-P., Arendt, E.-K., Kenneally, P.-M., McSweeney, P.-L.-H., and O'Neill, E.-E. 2002. Characterization of proteolysis during the ripening of semi-dry fermented sausages. Meat Sci. 62:205-216

Igarashi, T., Kono, Y., and Tanaka, K. 1996. Molecular cloning of manganese catalase from Lactobaccillus plantarum. J. Biol. Chem. 271:29521-29524

Iroyukifujita, H., Eiichiyokoyama, K., and Yoshikawa, M. 2000. Classification and antihypertensive activity of angiotensin I-coverting enzyme inhibitory peptides derived from food proteins. J. Food Sci. 65:564-569

Jahan-Mihan, A., Luhovyy, B.L., Khoury, D.E., and Harvey, A.G. 2011. Dietary proteins as determinants of metabolic and physiologic functions of the gastrointestinal tract. Nutri. 3:574-603

Jang,A.; Liu,X.D.; Shin,M.H.; Lee,B.D.; Lee,S.K.; Lee,J.H. and Jo,C. 2008. Antioxidative potential of raw breast meat from broiler chicks fed a dietary medicinal herb extract mix. Poul. Sci. 87:2382-2389

Kim, S.W., Mateo, R.D., Yin, Y-L., and Wu, G. 2007. Functional amino acids and fatty acids for enhancing productin performance of sows and piglets. Asian-Australian J. Animal Sci. 20(2):295-306

Kroll, J., and Rawel, H.M. 2001. Reactions of plant phenols with myoglobin: influence of chemical structure of the phenolic compounds. J. Food Sci. 66(1):48-58

Lebert, I., Leroy, S., Giammarinaro, P., Lebert, A., Chacornac, J.-P., Bover-Cid, S., Vidal-Carou, M. C., 
and Talon, R. 2007. Diversity of microorganisms in the environment and dry fermented sausages of small traditional French processing units. Meat Sci. 76:112-122

Leroy, F., Verluyten, J., and Vuyst, L. 2006. Functional meat starter cultures for improved sausage fermentation. Int. J. Food Micro. 106:270-285

Liu, Q., Kong, B., Xiong, Y.L., and Xia, X. 2010. Antioxidant activity and functional properties of porcine plasma protein hydrolysate as influenced by the degree of hydrolysis. Food Chem. 118:403-410

Lorenzo, J.-M., Michinel, M., López , M., and Carballo, J. 2000. Biochemical characteristic of two Spanish traditional dry-cured sausage varieties: Androla and Botillo. J. Food Comp. Anal. 13:809-817

Lücke, F.-K. 200o. Utilization of microbes to process and preserve meat. Meat Sci. 56:105-115

Mahae, N. and Chaiseri, S. 2009. Antioxidant activities and antioxidative components in extracts of Alpinia galangal (L.) Sw. Kasetsart J. (Nat. Sci.) 43:358-369

Martinez, L., Cilla, I., Beltrán, J A., and Roncalés, P. 2006. Effect of Capsicum annuum (red sweet and cayenne) and piper nigrum (black and white) pepper powders on the shelf life of fresh pork sausages packaged in modified atmosphere. J. Food Sci. 71(1):S48-S53

Neveu, V., Perez-Jimenez, J., Vos, F., Crespy, V., du Chaffaut, L., Mennen, L., Knox, C., Eisner, R., Cruz, J., Wishart, D., and Scalbert, A. 2010. Phenol-Explorer: an online comprehensive database on polyphenol contents in foods. Database, article ID bapo24, doi:10.1093/database/bapo24.

Okarini, I.A., Hari Purnomo, Aulanni am, and Liliek Eka Radiati. 2013. Proximate, total phenolic, antioxidant activity and amino acids profile of Bali indigenous chicken, spent laying hen and broiler breast fillet. Int. J. Poul. Sci. 12(7):415-420

Pramesti, G. 2005. Mahir Menggunakan SPSS 13.0 dalam Rancangan Percobaan. PT Elex Media Komputindo Kelompok Gramedia, Jakarta.
Samappito, W., Leenanon, B., and Levin, R.E. 2011. Microbiological characteristic of "Mhom", a Thai traditional meat sausage. The Open Food Sci. J. 5:31-36 Santé-Lhoutellier,V., Aubry, L., and Gatellier, P. 2007. Effect of oxidation on in vitro digestibility of skeletal muscle myofibrillar proteins. J. Agric. Food Chem. 55:5343-5348

Sanz, Y., and F. Toldrá. 2002. Purification and characterization of an arginine aminopeptidase from Lactobacillus sakei. App. Environ. Micro. 68(4):1980-1987

Siriken, B., Cadirci, O., Inat, G., Yenisey, C., Serter, M., and Ozdemir, M. 2009. Some microbiological and pysico-chemical quality of Turkish sucuk (sausage). J. Animal and Vet. Adv. 8(10):2027-2032

Toldrá, F., and Flores, M. 200o. The use of muscle enzymes as predictors of pork meat quality. Food Chem. 69:387-395

Udenigwe, C.C. and Aluko, R.E. 2012. Food proteinderived bioactive peptides: production, processing, and potential health benefits. J. Food Sci. 71(1):R11R24

Visessanguan, W., Benjakul, S., Riebroy, S., Yarchai, M., and Tapingkae, W. 2006. Changes in lipid composition and fatty acid profile of Nham, a Thai fermented pork sausage, during fermentation. Food Chem. 94:580-588

Wojciak, K.M, and Dolatowski. Z. J. 2012. Oxidative stability of femented meat products. Acta Sci. Pol. Tech. Alimen. 11(2):99-109

Zanardi, E., Ghidini, S., Battaglia, A., and Chizzolini, R. 2004. Lipolisis and lipid oxidation in fermented sausages depending on different processing conditions and different antioxidants. Meat Sci. 66:415-423

Zhang, W., Xiao, S., Samaraweera, H., Lee, E.J., and Ahn, D.U. 2010. Improving functional value of meat products. Meat Sci. 86 